\title{
EFL Students’ Problems in Writing Argumentative Essays
}

\author{
Agustinus Bambang Balinga Saputra ${ }^{1 *}$ Jumariati $^{2}$, Emma Rosana Febriyanti ${ }^{3}$ \\ 1,2,3 Lambung Mangkurat Univeristy \\ *Corresponding author. Email: a1b215001@mhs.ulm.ac.id
}

\begin{abstract}
Writing in a foreign language is not easy because students have to consider not only the content but also the vocabulary, grammar, and mechanics. This study aimed to investigate the problems that English students have in writing argumentative essays. The subjects of this research were 55 students who were enrolled in Advanced Writing course at English Language Education Study Program of FKIP Universitas Lambung Mangkurat. A descriptive design within mixed method approaches was applied. A questionnaire was distributed and an open-ended interview was carried out to reveal problems that students face in writing argumentative essays. Moreover, an analysis on students' argumentative essays was employed to confirm the findings from the questionnaire and interview. The results indicated that the students had problems in writing argumentative essays pertaining to cognitive aspects (lack of knowledge on the key features of an argumentative essay), linguistic aspects (content, grammar, organization, vocabulary, claim, and evidence), and psychology aspects (fear of making mistakes, lack of self-esteem, and low motivation) that affected them in writing. These findings demand attention from the lecturers of Advanced Writing course particularly on the needs of more explicit instruction on writing claims and providing evidence in argumentative essays. The findings also suggest that more effective approach of teaching argumentative writing is needed to overcome students' problems.
\end{abstract}

Keywords: Writing, Argumentative essay, Problems

\section{INTRODUCTION}

Writing is a communication language tool through a written form. As a tool, writing has a purpose to share and convey ideas to readers through an acceptable written form. Despite its benefits, writing is difficult. It becomes more difficult when students are writing in a language that is not their own [16]. Research shows that teaching writing to Indonesian students is challenging because at the same time they write, they are dealing with problems in using proper vocabulary and grammar $[2,10,18]$ and cultural differences between Indonesian and English [16]. Thus, experts consider that writing is the hardest part of learning English. Students have to deal with the challenges in transferring their thought and idea through written form. They also need to pay attention to the vocabulary, language use, organization, and mechanics.
Studies have been conducted to investigate students' abilities in argumentative writing. A research on advanced level students in EFL writing showed that students had poor abilities in writing argumentative essays $[1,7,12,13,14]$. In line with this result, research reveal that EFL learners commonly face problems with regard to vocabulary, grammar, organization, and mechanics while at the same time they need to deliver a decent piece of writing $[5,6,11,12]$. This confirms that writing is a difficult skill for EFL learners, let alone writing argumentative essays.

In Indonesian context, a comprehensive approach is needed to reveal university students' problems in writing argumentative essays. It is essential to reveal the problems students face pertaining to cognitive, linguistic, and psychological aspects to help students and teachers find ways to overcome the problems. Therefore, it is necessary to investigate deeply about what problems the students have in writing 
argumentative essays. Hence, this study is aimed to answer the following research question: "What problems do the advanced level students face in writing argumentative essays?"

\section{LITERATURE REVIEW}

Writing skills is considered challenging for most students as they face difficulties with the content, organization, vocabulary, and grammar $[6,8,10]$. Furthermore, EFL learners face problems in writing that originate from three sources namely psychological, linguistics, and cognitive aspects $[4,16]$ each of which needs attention from both the students themselves and the teachers. This is because having good ability in writing will enable students to perform good either in academic or career that require writing skills.

The goal of argumentative writing is to convince the readers. As any other essay, argumentative essay also consists of introduction, body, and conclusion. However, there are six key features in an argumentative essay namely claims, data, warrants, backing, qualifiers, and rebuttals [19,20]. The existence of the features characterize a good argumentative essay that is compelling to the readers.

Studies have been conducted regarding students' abilities in writing argumentative essay, students' problems in writing argumentative essays, and students' attitude toward writing. Research shows that EFL learners' ability in writing argumentative essay is average. It is affected by the respondents' low scores in grammar and lack of ability of composing organized essays $[1,5,11]$. Meanwhile, another study shows that Indonesian EFL learners face problems in three categories namely linguistics problems, cognitive problems, and psychological problems [15]. Moreover, another study reveals that although EFL learners have moderate attitude to writing, they view writing as difficult and stressful. Meanwhile, those who have high attitude mostly view writing as interesting and challenging [17].

\section{METHOD}

This study applied a descriptive design with mixedmethods approach. It is aimed to describe the problems of the advanced students of English Language Education Study Program of FKIP ULM in writing argumentative essays. Purposive sampling technique was implemented. Hence, the students who were enrolled in Advanced Writing course were taken as the subjects with total number 55 students.

The instruments used to collect the data were questionnaire, interview guideline, and document analysis guideline. The questionnaire consisted of 26 items covering the cognitive variables (the subjects' background knowledge about argumentative essay, linguistic variables (subjects' potential problems in writing argumentative essay dealing with the content, claim, data, rebuttal, organization, vocabulary, grammar, and mechanics), and psychological variables (subjects' fear of making mistakes, lack of interest, lack of self-esteem, lack of motivation, and bad mood condition). A semi-structure interview was used to reveal deep information concerning on the sources that cause students' problems and how the problems may affect them in writing. To support the data, analysis on students' writings was carried out by using a guideline consisted of the aspects of citation, supporting data, and punctuation. All the data was analyzed qualitatively.

\section{RESULT AND DISCUSSION}

\subsection{Cognitive Variables}

The findings showed that in the cognitive variable, that is the students' background knowledge about argumentative essay, 54 students $(98.2 \%)$ chose "agree" and "strongly agree" as their responses. On the second item, there are 52 students $(94.5 \%)$ chose "strongly agree" and "agree". On the third item, students mentioned that they know about the general structure of argumentative essay. It was proved by the data that 32 students $(51.8 \%)$ chose "strongly agree" and "agree" while 23 students $(41.8 \%)$ chose disagree.

Similar result were found in the interview showing that the students knew the definition, function, and generic structure of argumentative essay. However, most of them were failed to mention the key features of argumentative essay which were claim, data, warrant, backing, qualifier, and rebuttal. It was also found that the students had problem in collecting data. They explained that reading sources to support their argument needed a lot of time. It was also difficult to analyze the pros and cons of the data.

This finding proves the theory about sources of problems in writing may originate from three sources, namely psychological problems, linguistic problems, and cognitive problems [4]. It is also compatible with the research result of research from Rahmawati and Rahmatunnisa [15, 16] revealing that Indonesian EFL learners faced linguistics problems, cognitive problems, and psychological problems when they write paragraphs and essays.

\section{2. Linguistic Variables}

Linguistic variable of an argumentative essay which can become the sources of students' problems in writing argumentative essays consist of vocabulary, grammar, language use, and mechanics. In addition, there were three main elements of argumentative essay included in this variable namely claims, data, and rebuttal.

In the content aspect, majority of the subjects chose "strongly agree" and "agree" (80\% or 44 students) as their response to the questionnaire item of having 
difficulties in developing idea into paragraphs. It is also found that students had problems in providing supporting ideas for their argumentative essays (46 students or $83.6 \%$ ). On the contrary, the data showed that students had no problem in writing the concluding paragraph for their argumentative essays as 29 students $(52.7 \%)$ chose "disagree" and "strongly disagree".

The next aspect is organization. The data indicated that students had problems in organizing ideas following the structure of an argumentative essay as 43 students (78.1\%) chose "strongly agree" and "agree". Meanwhile, in the aspect of grammar, there were 44 students $(80 \%)$ who chose "strongly agree" and $83.6 \%$ (46 students) chose "agree". Finally, there were 32 students (58.1\%) who chose "agree" that they had problems in using conjunctions.

In vocabulary aspect, it was found that there were 43 students $(78.1 \%)$ chose "strongly agree" and "agree" as their responses to "I had difficulties in using the right vocabulary when I write an argumentative essay". Further, the interview revealed that they felt difficult in writing argumentative essays because they were afraid of making mistakes in explaining their argument. In contrast, they stated that they did not have difficulties in using punctuation as 31 students $(56.3 \%)$ "disagree" and "strongly disagree" to the statement on the item about problem in using punctuation. However, the interview revealed that three students $(5.5 \%)$ were sometimes unsure whether their writings have followed the right rules in mechanic use.

In the elements of argumentative essays, 8 students $(14.5 \%)$ chose "strongly agree" and $32(58.2 \%)$ of them chose "agree" on the item that they had troubles in making a claim for the topic of argumentative writing. Meanwhile, 30 students $(54.5 \%)$ chose "disagree" to respond to the item that stated "I have troubles in finding the data to support my claim". The interview revealed that they used the internet to search for the references to support their argument. However, both the questionnaire and interview results showed that they had problem in organizing the data and selecting the most relevant data to use in their essays. However, the interview found that two main problems regarding finding the data were it took much time for them to read different sources to gain a solid prove and it was challenging to analyze the pros and cons of the issue.

Analysis on students' essays was also employed to obtain a more comprehensive data. As stated, students had problem in providing data to support their argument. The following sample displays a poor essay since the writer did not cite experts' ideas to support his argument:

On the other hand, we also have to look to whom we apply the technology. If we apply it to students who are in their teens to adulthood, they can certainly understand the instructions for using technology clearly. Another case, if we apply to early childhood, they will certainly be confused following the instructions. Early childhood is very need an intense relationship between teacher and students. They just get to know the world, friends, and the school environment. Therefore, they must carry out interactions or physical contact directly so that socialization occurs between individuals with one another.

Another interesting finding is also found in students' essays since the essay did not display proper citation as follow:

As stated by Elbert Hubbard, a philosopher, that one machine can do the work of fifty ordinary man, but no machine can do the work of one extraordinary man.

In the rebuttal aspect, there was only one student who chose "strongly agree" and 42 students (76.4\%) chose "agree" which indicated that they had problem to provide rebuttal. Furthermore, they had problem in selecting the data to be included as the rebuttal since 50 students $(90.9 \%)$ chose "strongly agree" and "agree". These findings were confirmed by the results of the interview. The students explained that the complexity of the issue being argued and lack of relevant sources were some of the causes of why they had problems in providing rebuttal. Moreover, they had difficulties in paraphrasing and citing experts' ideas following the rules of academic writing.

The results indicate that students have problems in writing argumentative essays dealing with linguistic aspects. It is confirmed the statement by Nindya [11] that EFL students have some common problems in writing such as in content, organization, vocabulary, and grammar. In a similar vein, Jumariati, Syafii $[6,18]$ also mention that teaching writing to Indonesian students is challenging because at the same time the students write, they should deal with problems in using proper vocabulary and grammar. Therefore, writing argumentative essays is also challenging for them since the genre requires deep understanding on the issue and good abilities in thinking critically [7,12]. In the same line, all of these problems were also revealed in studies by Nindya, Rahmatunisa, Rahmawati $[11,15,16]$ that EFL learners faced the problems in three categories, those are linguistics problems, cognitive problems, and psychological problems.

\subsection{Psychological variable}

The third variables on the questionnaires were psychological variables. The questionnaires revealed that there were 42 students $(76.4 \%)$ agreed that fear of making mistakes was one of their problems when writing argumentative essay. Furthermore, this finding was in line with the interview result in which they admitted that fear of making mistakes is one of their problem. One of them stated that the fear in making 
mistakes usually occur when he writes, but it increases when he writes argumentative essay because the task demands critical analysis on an issue.

Another finding in the questionnaire showed that the students were lack of self-esteem when they write argumentative essay. Nine students (16.3\%) chose "strongly agree" and 30 students (54.5\%) chose "agree" as their responses. Furthermore, the interview showed that feeling not confident affected them in writing argumentative essays. Three students even explained that they were unsure about their writing because this genre requires deep understanding on an issue and good skills in arguing. Consequently, this genre puts them a lot of pressure to bear when writing it.

In conclusion, the students agreed that psychological aspects affect them in writing argumentative essays such as fear of making mistakes, lack of self-esteem, and low motivation. These findings are compatible with the theory from [4] who postulates that there are three main problems in writing, and one of them is psychological problems. The findings of this study were also similar to the findings of a research by Setyowati [17] that students who have a moderate attitude to writing view writing as difficult and stressful.

\section{CONCLUSION}

Based on the findings, it can be concluded that the students faced cognitive, linguistic, and psychological problems when they write argumentative essays. In cognitive aspects, the problem found is lack of knowledge on the key features of an argumentative essay. In linguistic aspects, the students have problems pertaining to the content, grammar, organization, vocabulary, claim, and evidence. Meanwhile, in psychological aspects they have problems with fear of making mistakes, lack of self-esteem, and low motivation. These findings demand attention from the lecturers of Advanced Writing course particularly on the needs of more explicit instruction on writing claims and providing evidence in argumentative essays. The findings also suggest that more effective approach of teaching argumentative writing is needed to overcome students' problems.

\section{AUTHORS' CONTRIBUTIONS}

Author 1 contributed to the reviewing of literature, designing research instruments, collecting the data, and analyzing the data. Author 2 contributed to the design of the research, data analysis, and writing the report. Author 3 contributed to literature review and writing format.

\section{ACKNOWLEDGMENTS}

The authors would like to address their gratitude to the instrument validator and the subjects of the research who were willing to participate both in the survey and interview sessions.

\section{REFERENCES}

[1] M. F. F. Abbas, Herdi. Solving The Students' Problems in Writing Argumentative Essay through Collaborative Writing Strategy, in: Proceedings of ENGLISH REVIEW: Journal of English Education, vol. 7, 2018, pp .105-114.

[2] A. Ariyanti, R. Fitriana, EFL students' difficulties and needs in essay writing. Advances in Social Science, Education, and Humanities Research (ASSEHR). vol. 158, 2017, pp 111-121.

[3] B. Briggs, R.J. Anne M. Coleman, M Morrison, , in: Proceedings of Research Methods in Educational Leadership \& Management (3rd Ed.). Croydon: CPI Group (UK). Ltd, 2012.

[4] D. Byrne, Teaching Writing Skills, Longman Group UK Limited, 1990.

[5] M.S. Husin, E. Nurbayani, The Ability of Indonesian EFL Learners in Writing Academic Papers, in: Proceedings of DINAMIKA ILMU, vol. 17,2017 pp. 237

[6] J. Jumariati, G.H. Sulistyo, Problem-Based Writing Instruction: Its Effect on Students' Skills in Argumentative Writing, in: Proceedings of Arab World English Journal, Vol.8, 2012, pp.88.

[7] M. Ka-kan-dee, S. Kaur, Argumentative Writing Difficulties of Thai English Major Students, in: Proceedings of The 2014 WEI International Academic, 2014, pp 193-207.

[8] F. Khodebandeh, M. Jafarigohar, H. Soleimani, \& F. Hemmati, F.Investigating Iranian EFL writing problems and examining back transfer, in: Proceedings of Asian EFL Journal. vol. 16, 2014, pp. 227-270.

[9] Y. Liunokas, Assessing Students' Ability in Writing Argumentative Essay at an Indonesian Senior High School, in: Proceedings of IDEAS: Journal of Language Teaching and Learning, Linguistics, and Literature, vol. 8, 2020, pp 284-296, doi:10.24256/ideasv8i1.1344

[10] C.Y. Ngabut, C.Y. Instructional Material of Writing. Palangka Raya: Faculty of Teacher Training and Education University of Palangka Raya, 2003.

[11] M.A. Nindya, U. Widiati, Cohesive devices in argumentative essays by Indonesian EFL learners, in: Proceedings of Journal on English as a Foreign 
Language, vol. 10, 2020, pp. 337-358, DOI. https://doi.org/10.23971/jefl.v10i2.1949

[12] B. Ozfidan, C. Mitchell, Detected Difficulties in Argumentative Writing: The Case of Culturally and Linguistically Saudi Backgrounded Students, in Proceedings of Journal of Ethnic and Cultural Studies, vol. 7, 2020, pp. 15-29. DOI: doi:10.29333/ejecs/382

[13] Y.A. Prananda, Students' Ability in Writing Paragraphs Using Structure of The Paragraph in Argumentative Essay By The Sixth Semester of English Study Program of Muhammadiyah University of Bengkulu, Bengkulu: English Education Study Program Department of Language and Arts Faculty of Teacher Training and Education Universitas Muhammadiyah Bengkulu. 2004.

[14] J. Peloghitis, Difficulties and strategies in argumentative writing: A qualitative analysis, In P. Clements, A. Krause, \& H. Brown, Transformation in language education. Tokyo, JALT. 2017.

[15] W. Rahmatunisa, Problems faced by EFL learners in writing argumentative essay, in: Proceedings of English Review: Journal of English Education, 2014.

[16] F.S. Rahmawati, B.Y. Cahyono, M. Anugerahwati, , Effect of story maps on EFL students' achievement in writing narrative texts, in: Proceedings of Journal on English as a Foreign Language, vol. 8, 2018, pp. 130-148. DOI: http://dx.doi.org/10.23971/jefl.v8i2.877

[17] L. Setyowati, S. Sukmawan, EFL_ Indonesian Students' Attitude toward Writing in English, in: Proceedings of Arab World English Journal (AWEJ) vol. 7, 2016

[18] M.L. Syafii, M.Z. Miftah, Venn-diagram strategy in EFL class to enhance learners' writing skill and motivation, in: Proceedings of Journal on English as a Foreign Language, vol. 10, 2020, pp. 141-162. DOI: https://doi.org/10.23971/jefl.v10i1.1556

[19] C. Whithaus, Claim-Evidence Structures in Environmental Science Writing: Modifying Toulmin's Model to Account for Multimodal Arguments, Technical Communication Quarterly. London: Routledge Informa Ltd Registered in England and Wales, 2012.

[20] C.R. Wolfe, Argumentation across the curriculum. Written Communication, vol. 28, 2011, pp. 193219. DOI: doi://10/1177/0741088311399236 